\title{
Comparing Learning-at-home Activities of Students Living in Cities and Those Living in Villages during the Covid-19 Pandemic
}

\author{
H. Herianto ${ }^{1}$, Andi Jusmiana ${ }^{2}$, Jusmawati Jusmawati ${ }^{3},{ }^{4}$ Zulkifli M, Satriawati Satriawati $^{5}$ \\ ${ }^{1}$ STKIP YAPTI Jeneponto, Jeneponto, Indonesia \\ Email: antoherianto47@gmail.com \\ ${ }^{2}$ Universitas Pejuang Republik Indonesia, Makassar, Indonesia \\ Email: andijusmiana@gmail.com \\ ${ }^{3}$ Universitas Mega Rezky, Makassar, Indonesia \\ Email: jcjusmawati030490@gmail.com \\ ${ }^{4}$ STAI DDI Kota Makassar, assar, Indonesia \\ Email: zulkifli.makmurmail@ugm.ac.id \\ ${ }^{5}$ Universitas Mega Rezky, Makassar, Indonesia \\ Email: satriawati.01@gmail.com
}

\begin{abstract}
The Indonesian government has set a new policy related to learning activities during the Covid-19 pandemic, namely learning from home online. This study aimed to compare students in the cities and the villages in terms of liveliness and obstacles they find in online-based learning. The study used a qualitative method with a descriptive approach. Data collection was done by in-depth interviews with research subjects, namely two students living in cities and two others living in villages. The results showed that all research subjects actively participated in lectures through online learning. The students who lived in cities only had constraints in terms of the cost of providing internet quota during the implementation of learning from home. Meanwhile, the students in the villages had more than that, namely 1) limited internet network, making them have to leave home; 2) cost of providing internet quota; 3) limited internet quota providers, and 4) lack of focus on lecture activities because the environment was not supportive (out of home). Based on these findings, this study concluded that all students who lived in cities and villages were actively participating in learning-from-home activities, but those who lived in villages had more obstacles.
\end{abstract}

Keywords: Learning Activity, Learning from Home, Covid-19 